\title{
Women and Organizational Capabilities in Seaweed Production in North Gorontalo
}

\author{
${ }^{1}$ SUKARMAN KAMULI, ${ }^{2}$ BASRI AMIN \\ ${ }^{1}$ Faculty of Social Sciences, State University of Gorontalo, Indonesia - 96128; \\ ${ }^{2}$ Research Institute for School \& Society-RISS, State University of Gorontalo, Indonesia \\ email: ${ }^{1}$ sukarman_kamuli@ung.ac.id; ${ }^{2}$ basri@ung.ac.id
}

\begin{abstract}
Despite the government support for economic development in some coastal areas in Indonesia, the paradigm about women's agency remains the same. This is because women are still marginalized. This paper focuses on looking at agencies of women in managing their resources. This study proves that women are active agents in coastal areas of North Gorontalo. Specifically, in the seaweed production, empirical evidences show significantly that women's associations succeeded in gaining economic advantages, participatory leadership, and had adaptability towards changes in technology and seaweed market. Applying a qualitative research approach, this study illustrates a number of policy subjects, organizational patterns, regional opportunity, and actors that support the centrality of women's organizational capabilities in the field of seaweed production in the north coast of Gorontalo. This study justifies the tendency in Gorontalo, and perhaps in other areas in Indonesia, that women groups have an economic reputation in the seaweed production because they are fully involved in all production processes.
\end{abstract}

Keywords: women agency, organizational capability, Gorontalo

\section{Introduction}

Empowerment program for fisherman is often gender-biased; the program focuses on men rather than women. In fact, women are also able to contribute to the economy of their family. Such an issue is the rationale for the establishment of women's organization by which it plays a major role in improving the well-being of people living in the coastal area. The organization believes that women are able to do jobs other than domestic works, i.e., supporting financial of their families. This is in line with the argument by Firdaus and Rahadian (2015: 241) that fisherman's wife plays a major role to support family income. Similarly, Widodo (2012: 6) argues that women's engagement in supporting her husband in fishery and other related works is significant to improve family's economic condition.

Generally, problems such as limited transportation access, poor school facilitiesincluding the library, limited quality human resources (such as teacher), electricity problem, communication, and health facilities obstruct people living in the coastal area. To solve these issues, government endeavors to improve the well-being of the society through empowerment program, providing facilities and infrastructures to support fisheries, and assistance and arrange workshops on fisheries. It aims at changing and developing the mindset of society in the coastal area.

However, the result of such interventions is not as expected. Problems are inevitable, even the implementation of the policy is not effective. The data identify some issues in the field, e.g., (1) the support is not welldistributed and given for groups rather than individual; (2) people's lack of understanding of facility maintenance, and; (3) the absence of expertise in providing the supports and aids. To cope with the above situation, the local government initiates to re-construct and change the policies, which are (1) grouporiented provision of supports; (2) promoting women's involvement in fisheries, and; (3) educating women to promote creativity and independence, specifically after the provision of supports. It should be noted that funding or changing of support providers lead to the

Received: July 30, 2017, Revision: March 13, 2018, Accepted: June 4, 2018

Print ISSN: 0215-8175; Online ISSN: 2303-2499. DOI: http://dx.doi.org/10.29313/mimbar.v34i1.2764.1-10

Accredited B based on the decree No.040/P/2014, valid on February, 18, 2014 until February, 18, 2019. Indexed by DOAJ, Sinta, IPI 
termination of the fund.

In the last few years, the issues on women fishermen have been addressed by the government, particularly in North Gorontalo. Still, the complexity of the development of people living in the coastal area, specifically the tendency in prioritizing performance of local economic organizations, constraints the government's effort. The key to cope with this issue is to pay attention to the opinion or experience of all members of such organizations. This research considers that the empowerment should focus on women living in the coastal area. It is because women's opportunities to involve in some sectors such as entrepreneurship are being marginalized (Ariwidodo, 2016; Zusmelia et al., 2012; Zaelany, 2010).

Officers from Department of Fisheries and Marine partake in assisting the workshops for people in coastal area. Each of them assists one group of fishermen. The purpose of the establishment of the group is to promote the sustainability of fishermen group. On top of that, every group members can control their performance. The government expects that the group enables all of its members to explore their potential, e.g., organizational skill, leadership, managerial, solidarity, and decision making to help achieve the target. Moreover, the establishment of fishermen group eases the empowerment program, especially broadening the insight and polishing the skills of the fishermen society (Kamuli, 2014: 57).

This study discusses on how the women seaweed farmers in the coastal area of North Gorontalo strive to prove their organizational capabilities. It observes their skill in organizational arrangement and independence. Such achievement is not about the legitimacy of women group in seaweed cultivation. The key lies on the women's ability to manage the available resources (natural and supportive conditions) and external resources (government assistance, empowerment programs, and assistance). This research also aims at providing a platform where experts can share their ideas and findings local wisdom and women empowerment, specifically the society in coastal area in Indonesia.

Women fishermen should go to work in their leisure time to (1) fulfill the needs of their family which become more demanding and complex; (2) adjust with the increase of prices of both primary and secondary needs; ( 3 ) contribute to earning more income to support the work of their husband. In addition, more job opportunities and changes in husband's perspective regarding career women are other reasons why women should help and support the economic condition of their family.

The main reason above overhauls the paradigm of fishermen community renowned for their paternalistic ideology. On the other hand, male fishermen realize that the wife also needs to be involved in fulfilling the family's economic needs. In response to such arguments, Handayani and Wayan (2009: 1-2) explain that women in coastal areas are no longer demanding equal rights because they are able to help meet the family needs. Women are now capable of taking part in public sector while carrying out their domestic duties.

The above discussion represents women's effort to alleviate poverty and improving their well-being. In Gorontalo, the issue of poverty in fishermen community blames on the limited transportation and market access; this also due to the geographical aspect of the area. The government endeavor to cope with the issue and improve the productivity of the fishermen through the empowerment program with the main target of women fishermen. That being said, the program also helps to preserve fishermen's environment. Other programs, e.g., workshops and seminars on aquaculture are also essential to further improve the fishermen's work. The government can also cooperate with the society to implement sustainable empowerment for local organizations and enterprises.

Efforts to train the performance should accompany the participation of women fishermen. One of the attempts is to monitoring the activities of women's performance from the beginning to the conduct of the activity. In addition, providing spaces for evaluation of activities is also required. This is echoing the results seen in Zulfida et al. (2015: 310) that "participatory approach" is effective to encourage community participation in the development context. This approach involves communities in all activities starting from the planning, implementation, controlling, and all the way to maximize the productivity.

The approach refers to the empowerment to promote the activity of communities and enables them to comprehend that they are an important part of a program. 
In response to this, Santoso and Priyono (2012: 182) mentions some considerations in empowering communities, such as (1) promoting awareness; (2) developing interest; (3) assessment; (4) small-scale experiments; and (5) the application the problem-solving. Taking these aspects into account promotes the awareness of society to do something productively.

In this research, women fishermen play a major role in supporting domestic life. Family economic conditions often cause household disputes. According to Prijono and Pranarka (1996: 61), one of the goals of the empowerment program is to improve the quality of productive family. Similarly, Friedman (1981) argues that household has three major powers, i.e., social, politics, and psychology. Social power associates with access to the fundamentals of production, e.g., information, knowledge and skills, participation in organizations, and financial resources. A good household economic condition will improve the ability to earn more living.

One thing that needs to be emphasized in fostering community participation is to always put the orientation towards providing assistance without considering its impact. Some communities in Gorontalo tend to be over-dependence on the provision of government aid and supports (Kamuli, 2015). In reality, the provision of aid has no legal impact on the community due to the lack of compensation if the objective is not met. However, the community will lose the sense of belonging and responsibility when it comes to the sociological dimension of development. Raising public awareness and responsibility is the issue in promoting the participation of the community. Commitment also contributes to the success and sustainability of a business in society.

Several aspects should be taken into account in advancing the roles of women fishermen. These aspects are namely (1) educating the objectives of the program to promote participation of the society; (2) workshops; and (3) accompanying the activities of women's organization (Zulfida et al., 2015: 314). However, there are some issues in implementing policies in the coastal area. Some of the examples are the limited number of officers for the empowerment program and the lack of sustainable organizational enhancement (Kamuli, 2015). The officers often reluctant to work in remote areas which have limited access to communication; they prefer to work in cities instead.

\section{Research Methodology}

This research employed qualitative method to explore the issue regarding the community of women seaweed farmers in North Gorontalo and its organizational capabilities. The data were selected through data reduction prior to proceeding to steps, i.e., classification, interpretation and connecting the themes of the data (Bungin, 2009). Some findings were developed into some thematic discussions to find out its relevance with the contexts of the data (Dey, 2005).

In collecting the data, this field research used observation and semi-structured interview with the participants from Anggrek District, North Gorontalo Regency, Gorontalo Province. These processes were conducted starting from May to July 2017. The participants consisted of 15 people from five communities of seaweed farmers at Ilodulunga, Langge, and Tolango village. All activities of these communities were observed three times. To obtain in-depth data, some stakeholders also participated in the interview. These stakeholders involved instructor of the empowerment program, officers from aquaculture division, Department of Marine and Fisheries, as well as experts and scholars in fisheries and aquaculture. Thematic data based on case studies procedures analysis were selected to examine the data; it consisted of three steps, such as (1) the determination of the unit of analysis; (2) intensive interview regarding the selected cases and sites of observation; and (3) documentation (the documents were from the groups or institutions) (Berg, 2007: 264-90).

\section{Seaweed Farming at Coastal Area of North Gorontalo}

The coastal landscape of North Gorontalo is perfect for seaweed farming. Several islands surround the condition of this area; it is relatively sloping, and there are some small bays. According to the data of Department of Marine and Fisheries, North Gorontalo regency (2017), around 3,395 hectares of the coastal areas in several main districts of the regency hold potential to cultivate seaweeds. Some of the districts, such as Anggrek, Kwandang, and Ponelo have the areas for cultivating 
seaweeds (Amin, 2012).

The area of seaweed planting in these districts will be expanded; the expansion of each area is 1,575 hectares (in Kwandang district), 1,070 hectares (in Anggrek district), 700 hectares (in Ponelo Islands), and 50 hectares (in Sumalata Timur district). However, the target can not be achieved because the development of seaweed farming in this area was not that effective. In 2005, the regency had 5,537 hectares of the coastal area in North Gorontalo regency for aquaculture activities (Department of Marine and Fisheries). This indicates that the development of the program is not effective.

Despite the above issue, there has been a rise in the production of seaweed in North Gorontalo regency since 2010 with the production rate of 18,821 tons. It is revealed that the production rate of this commodity increases significantly to 28,288 tons in 2012 . This trend happens in 2015 where the number of commodity production rose to 29,540 tons. However, data from Department of Marine and Fisheries Gorontalo regency (2017) reports that this number dropped to 26,633 tons in 2016.

The above findings indicate that the government has designed the plan for developing the sector since 2007. It is revealed that only 10,331 out of 20,621 hectares of the coastal area in North Gorontalo have been occupied as a seaweed cultivation area. Based on the data of 2010-2015, the trend of the expansion of cultivation area is the same as the results of its production. The contributing factors affecting such a trend are climates, quality of seaweed seeds, cultivation of seaweeds, market demands, consumers, and farming skills as well as the post-harvest management of the seaweed farmers.

This research finds that this commodity is worth developing for several reasons; 1 ) the wide availability of land; 2) production that keeps improving consistently; and 3) consumer demand, both for cultivation and market demands in some cities, such as Palu, Makassar, and Surabaya. Despite the decreases of the commodity in market demands, the help from fisheries instructors is able to bridge the farmers and the consumers from all around Sulawesi.

\section{Women's Agency and the Legitimacy}

Gorontalo women have a long history in shaping the thinking, organizing, and supporting their family (Amin, 2016). Decisionmakers still apply the traditional concept in regulating the women living in the coastal area. The key concepts of this context are capital factor, financing system, technology, human resources, facilities and infrastructure, while market access is key variables (Nadjib, 2015; Fajariyah \& Santoso, 2015; Purwanti, 2010; Kusnadi, 2007). Among these factors, however, the one who is responsible for the task can be identified as "resources" that can be managed and improved.

Organizational capabilities of women fishermen on the northern coast of Gorontalo are established from the experience of the women in cultivating seaweed; they consider that this commodity is well-suited to their skills. This aquaculture activity has relatively fast production and able to improve the welfare of fishermen households. Continuous support from the government promotes the sustainability of the resources of women fishermen community.

Women play a major role in seaweed farming. However, most people value their contribution from the perspective of the aquaculture product and the logic of market economy despite the fact that women are capable of improving the welfare of their family. The organizational capability enables the women to cope with the economic downturn. Women's effort in alleviating the poverty is shown by how they manage to maintain their seaweed farming despite that this commodity is prone to fluctuation. In fact, seaweed farming holds potentials to earn more living like the seaweed business in Poteran, Sumenap (Fajariyah \& Santoso, 2015).

Although seaweed can be regarded as a commodity that does not require expensive technology, the processing of seaweed is quite difficult. As a result, coastal communities change their management patterns, adapt to the risks that will arise and divide work between family and fishing communities. In this research, gender relations encourage fishing communities to accept "new culture" in their work. Then, at the same time, they reinforce the new work culture as their capital in response to economic opportunities that will benefit them.

Some studies show that most of women fishermen play a passive role regarding family support and only waiting for their husbands to come home with catches from the sea 
or cultivated goods. On the contrary, some women living in the coastal area prefer to do jobs other than helping their husband (fisheries) (Ariwidodo, 2016; Kusnadi, 2009). Such a situation also persists in families owning home-based fishpond business (Amin, 2014). This contrasts to seaweed farming where women are responsible for all the conduct of seaweed cultivation as shown in North Gorontalo regency. It remarks women's contribution, meaning that women are capable of owning their business and benefit much from the seaweed farming and production.

Although the involvement of women in seaweed cultivation in North Gorontalo is quantitatively small (16.36\%), the legitimacy they consolidate is increasingly significant. This occurs in some districts particularly in Anggrek district with the most farmer communities (36 communities). The data reports that $20.90 \%$ of the seaweed farmers at this district are women. The legitimacy of women is developed through group leadership and technical capability in every process of seaweed production all the way to marketing patterns developed by women. This shows that women contribute significantly in ensuring the sustainability of the production and the endurance of the seaweed economy. It is also useful in the face of market changes and socio-economic pressures.

The Table 1 provides the information regarding the areas, numbers of farmer's group, and the workers. It also shows the number of women fishermen in every cultivation areas in North Gorontalo regency.

Therefore, women's involvement which determines the production process of seaweed is emphasizing the agency of women themselves. This fact is not only a "working division" according to sexuality (Ford and Parker, 2008), but also a description of the particular legitimacy managed by women themselves based on "the work and the time" they allocate in seaweed commodities (Purwanti, 2010). At the next level, women's positions are no longer rely on the recognition of their socio-economic environment, including from their family base (as a production strength), but as the leading (organizational) agency of seaweed farming business.

At further level, women occupy social and organizational legitimacy, so that some rational footings are formed among them as well as when they utilize various supports (capital and equipment support) from regency or provincial governments. From this point, the foundation for a women's agency in the coastal area is formed and consolidates action, although it is impossible to separate it from the structural processes they manage and negotiate (Giddens, 1984).

In the work structure of seaweed sector, women have a strong legitimacy. Since the work they allocate at each stage of seaweed farming is increasingly dominant, the legitimacy is gradually more accustomed. Nevertheless, it should be underlined that the legitimacy is not designed earlier by women's communities. Instead, it is a product of intense interaction among local farmer communities, the economic opportunities for fishermen families through the commodities of seaweed, and their experience of endurance to be productive continually in facing market shocks and changing business environment conditions. On the other hand, the legitimacy is also growing due to the adaptability of women in applying work "technology" that is relatively practical, profitable and comfortable for them in doing their work. Women have their own superiority compared to men, especially regarding the accuracy of their technical works as well as their skills in sustaining such a working environment of seaweed farming.

\section{Organizational Capabilities and Women's Community}

Although seaweed business group is a formal institution that unites female farmers

Table 1

Seaweed Farmers Community in North Gorontalo in 2016-2017

\begin{tabular}{llll}
\hline DISTRICT & $\begin{array}{l}\text { SEAWEED } \\
\text { COMMUNITY }\end{array}$ & NUMBER OF FARMERS & FEMALE FARMERS \\
\hline Kwandang & 5 Groups & 46 Farmers (M/F) & 4 Farmers $(8,70 \%)$ \\
Ponelo Kepulauan & 20 Groups & 138 Farmers (M/F) & 12 Farmers $(8,70 \%)$ \\
Anggrek & 36 Groups & 311 Farmers (M/F) & 65 Farmers $(20,90 \%)$ \\
TOTAL & 61 Groups & 495 Farmers (M/F) & 81 Farmers $(16,36 \%)$ \\
\hline
\end{tabular}

Source: Office of Maritime Affairs and Fisheries of North Gorontalo 2017 (processed data). 
in North Gorontalo, the organization they establish has a long-term hidden power. After passing some economic shocks such as the undeveloped price of seaweed in North Gorontalo, the women's communities build up trust and intense communication with the seaweed business extension workers prepared by local government.

Some of the farming extension workers in North Gorontalo are very active in communication, and by that, new social capital is grown in the form of mutual trust between seaweed farmers and extension workers. The extension workers play an important role as they do not only assist the strengthening of women's technical capacity in farming activities, but also become active connectors of seaweed market information and buyers in Gorontalo and from the surrounding area. They even use social media to help seaweed marketing from North Gorontalo to other areas, such as Palu of Central Sulawesi, Ujung Pandang of South Sulawesi, and even Surabaya of East Java.

Mentoring is the most beneficial thing of the empowerment activities. Although each extension worker has his own interest in delivering progress reports at some point in farming business and other fishery businesses, they also build up commitment and intense communication with farmer communities. During our fieldwork (May-July 2017) in Anggrek district of North Gorontalo, we saw that the presence of extension workers was a source of motivation for the seaweed women farmer communities. They are like loyal friends sharing stories, including how they are together in encountering price problems often done by the middlemen that almost every time are present in their working activities.

Until the end of 2017, 61 communities of seaweed farming business were officially registered in North Gorontalo with 36 of them located in Anggrek district and 20 communities in Ponelo Island district. Although the provincial government regularly provides annual capital support as well as the same purpose is implemented by Maritime Affairs and Fisheries Office of North Gorontalo Regency, the response of each community varies from village to village. This is due to the difference between the successful and failed experiences, mentoring intensity, and variations in organizational (community) capability of farming business developed in each village or coastal area.
In general, seaweed farming can be done through two primary methods; by using floating rafts and long-line straps. From the seaweeds production, it does not need a certain feed that will disrupt the aquatic environment. Seaweed is even able to absorb certain organic nutrients to be utilized for its growth (Erlania \& Radiarta, 2015). Nonetheless, for some kinds of seaweeds, the potential for disease is quite common; hence, seaweed farmers tend to choose Spinosum type. This is a disease-resistant type, although the price in the market is relatively lower than others compared to Cottonii. In North Gorontalo, Spinosum is more popular and becomes the farmers' favorite type. Currently, (June 2017 and January 2018), the price of Cottonii-typed seaweed is IDR 6000/ $\mathrm{kg}$, and there are two tons of seaweeds ready to be sold by the farmers in Anggrek district.

In the process of seaweed production, some activities involve women at the phases when the seaweed seeds begin to be farmed (tying seaweed seeds along the lines), the process of harvesting (cutting and separating seaweeds), drying activities, and other postharvest activities (Ariwidodo, 2016). Although the initial action is developed in coastal areas, the further processes such as drying, quality control, packaging, and marketing usually continue to do in seaweed farmers' houses. Of all these intense activities, the claim of "superiority" for women's skills is acknowledged, both by themselves and local communities, including their families, extension workers, and government apparatuses, especially Maritime Affairs and Fisheries Office of North Gorontalo Regency.

For example, a farming extension worker in North Gorontalo who has been working since 2008 named Novi admits:

"Seaweed is a commodity that is very
close to women. They work diligently
and thoroughly in which it determines
the success of seaweeds production" (NP,
$20 / 7 / 17)$.

Technically, the confession also comes from a practitioner of fishery and farming, Nain Ismail, who is explaining:

"women cut the seaweeds neatly; even their cuts are straight. When they tie the seaweeds in the lines, they are not in a rush, so that the seaweeds are not easily detached in its growth period. In some cases, they even cut the seaweeds by using natural materials such as Sembilu (sliver 
of bamboo that is thin and sharp, bamboo splinter). This is really great because it helps the acceleration (branching) and the fertility of the seaweeds...." (NI, $7 / 17 / 2010$ ).

For the same job that mainly done during the harvest time, male farmers tend to drag seaweeds on the sand which wounded them due to the friction on the sand or gravel at the beach, including when the seaweeds are placed in the tarpaulins of shelter. Such a treatment does influence the condition of the crop, and in the medium-term, the production would gradually decreases.

It is evident that "treatment" in the production process needs practical skill and perception, and requires certain thoroughness and diligence. This is where women actualize their skills, which may be due to their perceptions of the production quantity, quality, and price in the market. Women have a strong-looking intention in seaweed sector because it is not as physically draining in a free and risky nature as done by fishermen. For them as farmers, their focus is to maintain and harvest the seaweeds at the right time while preparing some parts for quality seeds for the next planting season. The quality seeds are divided into two parts: 1 ) seeds for their own community; and 2) request of nearby areas, such as Popayato and Boalemo. After the seeds are separated, the process of drying is done for other part which is further ready to be sold.

Although seaweed business group is a formal institution that unites coastal women in North Gorontalo, their economic aspirations have something to do with the development of the seaweed market itself. In North Gorontalo since 2016 , although the production continues to grow through active communities, yet the development of entrepreneurs (collectors) has decreased. In fact, through seaweed collection traders, seaweed production of North Gorontalo can enter the regional market in Sulawesi, particularly through the route of Central Sulawesi, Bitung, or Surabaya.

Every farming community commonly consists of 10 members. By this amount, the work can be effective and support the improvement of the livelihood of community members through seaweed farming business. Seaweed farming communities are led by women who have an excellent organizational skill, although their scale of work is limited to seaweed commodities. However, their capability of managing the products they produce results in welfare changes at the community level. The culture of discussion and division of work is carried out through several work sites, among others are in seaweed shelters at the beach, and drying and marketing activities around their houses.

Their endurance to keep being productive is built on the ability to support and help each other across the communities. This takes place when the harvest season comes or when the seed stocks are limited. Usually, when seed supports from the government are limited and uneven for all communities, some of them decide to give seeds for each other. From here, farmers' organizations execute their adaptation strategies toward the limitations of the government supports, and at the same time, they are struggling to access lucrative markets. As far as we can find out in the field, the role of the exploitative middlemen has had little effect because of the community solidarity and mentoring of the extension workers.

On a macro scale, this study also confirms that women's empowerment program should be based on existing resources among women by looking at the sustainable institutionalization process. Through strong institutionalization, community-based empowerment sustainability will find its ideal economic scale, i.e. as the social capital of coastal communities whose growth is nurtured by a combination of families, communities, partnerships, mentoring, and cluster-based participative policies of countries with efficient financing.

In the long-term, the basis of women's organizational experience will naturally become a resource that will continue to be activated. It should also be seen as a sustainable empowerment variable of a country, particularly in interactive leadership practices among women that have been shown to have a significant impact on their entrepreneurship sector (Moore \& Buttner 1997: 99).

The following ideas will explain the relationship between women's agency and the policy factors or government supports in North Gorontalo. This relationship needs to be emphasized because at the time seaweed farming businesses are carried out and widespread throughout Indonesia, North Gorontalo is one of the areas that responds quickly. No wonder that various stories of successful seaweed farmers in Kepulauan 
Ponelo in the mid-1990s have been recorded. Since then, mutual involvement between government supports (usually in the form of direct assistance) and community formation determine each other.

\section{Government Policy and Coastal Com- munity Response}

According to the central government, the potential of coastal areas that support seaweed farming is 769.452 hectares since 2007. This area continues to increase after seeing the reality in the market that the needs for raw materials and processed seaweeds are getting bigger. Since 2007, Indonesia is listed as the world's largest exporter of seaweeds with high economic value and can absorb a lot of labors (Fajariyah \& Santoso, 2015).

At the regional level, government policy to strengthen the seaweeds' economic base is manifested in a similar way. Some conditions must be met, especially related to the status of legal entity of the farming communities and the business feasibility as confirmed by the regency-level Maritime Affairs and Fishery Office. In this context, farmers are formally required to become members of cooperatives (Koperasi). However, the mechanism of government support to seaweed farmers is relatively simple that is through the proposal of the community line and regency government and/or through a provincial assessment based on the direct proposal of the community or the legislative members of the Regional People's Representative Assembly.

Regarding the quantity, for the case of North Gorontalo, annual supports are fluctuating. In 2016/2017, there were ten communities of seaweed farming supported by the provincial government along with five communities supported by the regency government of North Gorontalo.

Farmers are always waiting for the government supports. They even depend on seeds support from the government for quite a long period. They also receive facilities and infrastructure, for example, seeds and lines (long-line straps). Uniquely, North Gorontalo received a program injection for poverty alleviation in the form of capacity building assistance (mentoring) from an international institution called CCDP-International Fund for Agricultural Development (IFAD) in 20132017.

CCDP-IFAD as an organization under the United Nations (UN) based in Rome, Italy, has a mission of providing soft loans to the Government of Indonesia and grants for the financing of the Coastal Community Development Project from 2013 to 2017. It is directed at (1) poverty alleviation (propoor); (2) job creation (pro-job); 3) economic development growth (pro-growth); (4) sustainable development (pro-sustainability).

\section{Conclusion}

Women in the coastal area of North Gorontalo play a role in an institutionalized agency. They are actively supporting their family's income and helping their husbands in the fishery sector and another service of economic sectors. Women's agencies have come to new and more complex spaces as they become main persons in the production process, building up their commodity bargaining power in the market as well as organizational strengths that can take advantage of multiple government policy interventions. Women are the strength of the communities in which through the "community culture," their leadership is legitimized.

This study suggests that women's agencies should be the basic principles of coastal community's empowerment. With women's agencies, the assumptions that place them in a passive and marginal position must be gradually eliminated, as this will widen our analysis superficiality or simplify the exaggerated concepts in empowerment activities and the study of development policies for coastal communities. Thus, significant cases proved that women's agencies in the productive economic sectors should be placed as a source of aspiration about women's adaptability, concerning technology, household economic management, and their endurance in handling market shocks.

\section{References}

Amin, B (2016). "Menggerakkan Roda Zaman: Rujukan Sejarah Perempuan Gorontalo [Moving the Era: Historical Reference of Gorontalo Women]". Jakarta: PIP Press

Amin, B (2014). Mempertahankan Ruang Hidup: Konservasi dan Budaya di Teluk Tomini [Maintaining the Living Space: Conservation and Culture in Tomini Bay]. Jurnal Masyarakat dan Budaya LIPI, Vol. 16, No. 1, pp: 113-135.

Amin, B., Pristiwanto., Kadir, I.A., Razak, 
I \& Boneka, F.B. (2012) "Nelayan dan Perubahan Ruang di Pesisir Utara Gorontalo [Fishermen and Space Changes in North Coastal Area of Gorontalo]". Yogyakarta: Kepel Press \& BPNB Manado.

Ariwidodo, E. (2016). Pekerja Perempuan Pesisir Sektor Pembudidayaan Rumput Laut Dalam Perspektif Analisis Gender di Pakandangan Tengah, Kabupaten Sumenap [Coastal Female Farmers of Seaweed Farming Sector from the Perspective of Gender Analysis in Pakandangan Tengah, Sumenap Regency], Nuansa, Vol. 13, No. 2 Juli - Desember, pp: 343

Berg, B.L. (2007). "Qualitative Research Methods for Social Sciences". Pearson: New York

Bungin, B. (2009). "Penelitian Kualitatif [Qualitative Research]". Jakarta: PT. FajarInterpratama Offset

Dey, I. (2005). "Qualitative Data Analysis: A User-Friendly Guide for Social Scientists". New York \& London: Routledge.

Dinas Kelautan dan Perikanan Gorut (Department of Marine and Fisheries Gorontalo regency). (2017). Laporan Perikanan Kelautan North Gorontalo [Report of Fisheries and Marine of North Gorontalo]. Kwandang: Dinas KKP

Erlania \& Radiarta, I.N. (2015). Pengembangan Budidaya Rumput Laut: Implikasi Penerapan Blue Economy di Teluk Sereweh, Nusa Tenggara Barat [Development of Seaweed Farming: The Implication of Blue Economy Implementation in Sereweh Bay, Nusa Tenggara Barat], Media Akuakultur, Vol. 10, No. 2, pp: 97-101.

Fajariyah, N. \& Santoso, B. (2015). Penentuan Klaster Pengembangan Ekonomi Lokal Berbasis Rumput Laut di Pulau Poteran, Kabupaten Sumenap [Determining Seaweed-Based Local Economic Development Cluster in Poteran Island, Sumenap Regency], Jurnal Teknik ITS, Vol. 4. No. 2, pp: 70-75

Firdaus dan Rahadian (2015). Peran Istri Nelayan dalam Meningkatkan Pendapatan Rumah Tangga [The Role of Fishermen's Wives in Increasing Household Income]. Jurnal Sosek KP Vol. 10 No. 2, pp: 241249.

Ford, M \& Parker, L. (2008) "Women and Work in Indonesia". London \& New York: Routledge.

Friedman, J. (1981) Kemiskinan Urban di Amerika Latin, dalam Ala, A.B (ed). Kemiskinan dan Strategi Memerangi Kemiskinan [Urban Poverty in Latin America, in Ala, A.B (ed). Poverty and Strategy of Combating Poverty]. Yogyakarta: Liberti.

Giddens, A. (1984) "The Constitution of Society: Outline of the Theory of Structuration". Cambridge: Polity Press

Handayani and Wayan, A.P. (2009). Kontribusi Pendapatan Ibu Rumah Tangga Pembuat Makanan Olahan terhadap Pendapatan Keluarga [Income Contribution of the Housewife as the Processed Foods Producer towards Family Income]. Piramida Vol. V No 1, pp:1-2.

Kamuli, S. (2015). "Minapolitan: Dimensi Kebijakan, Kelembagaan, dan Pemberdayaan Nelayan di North Gorontalo [Minapolitan: Dimension of Fishermen Policy, Institution, and Empowerment in North Gorontalo]". Jakarta: PIP Press

Kamuli, S. (2014). "Evaluasi tentang Implementasi Kebijakan Pengembangan Kawasan Minapolitan di Kabupaten North Gorontalo [Evaluation of the Policy Implementation of Developing Minapolitan Area in North Gorontalo Regency]". MIMBAR, Vol. 30, No. 1. pp: 53-61.

Kusnadi. (2007). "Jaminan Sosial Nelayan [Social Security of Fishermen]". Yogyakarta: LKiS

Kusnadi. (2009). "Keberdayaan Nelayan dan Dinamika Ekonomi Pesisir [Fishermen Empowerment and Coastal Economy Dynamics]". Yogyakarta: Ar-Ruzz Media.

Moore, D.P and Buttner, E.H. (1997). "Women Entrepreneurs: Moving Beyond the Glass Ceiling". London: Sage Publication.

Nadjib, M. (2015). "Sistem Pembiayaan Nelayan [Financing System of Fishermen]". Jakarta: LIPI Press

Prijono dan Pranarka (1996). "Pemberdayaan: Konsep, Kebijakan, dan Implementasi [Empowerment: Concept, Policy, and Implementation]". Jakarta: CSIS.

Purwanti, P. (2010) "Model Ekonomi Rumah Tangga Nelayan Skala Kecil [Economic Model of Fishermen Household in Small Scale]". Malang: UB Press

Santoso dan Priyono (2012). Desiminasi Model Pemberdayaan Masyarakat Desa Melalui Pengelolaan Agrowisata [Dissemination of Rural Community Empowerment Model through Agro-tourism Management]. Mimbar, Vol. 28, No. 2, pp: 181-190.

Widodo, Slamet (2012). Peran Perempuan dalam Sistem Nafkah Rumah Tangga Nelayan [The Role of Women in Livelihood of Fishermen Household]. Prosiding Seminar Nasional: Kedaulatan Pangan dan Energi. Fakultas Pertanian Universitas Trunojoyo Jawa Timur. 
Zaelany, A.A. (2010) Peran Perempuan pada Ritual Kenelayanan dan Perbekalan Mencari Ikan [Women in Fishing Rituals and Provisions]. Jurnal Kependudukan Indonesia LIPI, Vol. V, No. 2, pp: 73-89

Zulfida, I., Fauzi, A., Rustiadi, E \& Syaukat, Y. (2015) Kinerja Program Nasional Pemberdayaan Masyarakat Mandiri Perdesaan di Kabupaten Bandung [The Performance of National Program of Rural
Community Empowerment in Bandung Regency], Mimbar, Vol. 31, No. 2, pp: 307-318.

Zusmelia., Dasrizal, \& Yeni Erita (2012) Model Pengembangan Enterpreneurship dalam Pemberdayaan Ekonomi Rumah Tangga di Minangkabau [The Entrepreneurship Development Model in Household Economic Empowerment in Minangkabau], Mimbar, Vol. 28, No. 2, pp: 125-134. 